\title{
PENGARUH TINGKAT KEPERCAYAAN MASYARAKAT TENTANG COVID-19 TERHADAP KEPATUHAN MENJALANKAN PROTOKOL KESEHATAN PADA MASA PANDEMI COVID-19
}

\section{THE EFFECT OF COMMUNITY TRUST REGARDING COVID-19 ON THE COMPLIANCE OF HEALTH PROTOCOL IMPLEMENTATION DURING COVID-19 PANDEMICS}

\author{
Muslim $^{\bowtie}$, Herlina A.N Nasution \\ Prodi Sarjana Keperawatan, Universitas Bina Bangsa Getsempena, Jln. Tanggul Krueng Lamnyong No.34, Rukoh, Kec. \\ Syiah Kuala, Kota Banda Aceh. Indonesia \\ Correspondence Email : nasoetion.lina@gmail.com
}

\begin{abstract}
ABSTRAK
Virus corona merupakan virus berbahaya yang menyerang saluran pernapasan dan menyebabkan demam tinggi, batuk, flu, sesak napas serta nyeri tenggorokan. Cara yang dapat dilakukan untuk mencegah tertularnya Covid-19 yaitu menjalankan protokol kesehatan. Di Kabupaten Aceh Utara masih banyak masyarakat tidak patuh untuk menjalankan protokol kesehatan tersebut. Hal tersebut dikarenakan banyak masyarakat belum begitu mempercayai penyakit Covid-19. Penelitian ini bertujuan mengidentifikasi pengaruh tingkat kepercayaan masyarakat tentang Covid-19 terhadap kepatuhan menjalankan protokol kesehatan pada masa pandemi Covid-19. Jenis penelitian ini yaitu quantitative dengan desain korelasi analitik dengan cross sectional. Pengambilan sampel dengan teknik convenience sampling dengan jumlah 175 responden. Analisis data secara uji Chi-Square. Hasil penelitian menunjukkan sebanyak 67,4\% responden memiliki tingkat kepercayaan dalam kategori tidak percaya dan sebanyak $82,9 \%$ responden tidak patuh dalam menjalankan protokol kesehatan. Ada pengaruh tingkat kepercayaan masyarakat tentang Covid-19 terhadap kepatuhan menjalankan protokol kesehatan pada masa pandemi Covid-19 masyarakat di Desa Lueng Bata Kecamatan Baktiya Kabupaten Aceh Utara $(p=0,000)$. Diharapkan kepada petugas kesehatan terutama perawat lebih optimal dalam memberikan pendidikan kesehatan untuk meningkatkan kepercayaan masyarakat tentang Covid-19 sehingga masyarakat patuh dalam menjalankan protokol kesehatan.
\end{abstract}

Kata kunci: covid-19; kepatuhan; protokol kesehatan; tingkat kepercayaan.

\begin{abstract}
Corona virus is a dangerous virus that attacks the respiratory tract and causes high fever, cough, flu, shortness of breath and sore throat. One way to prevent the spread of COVID-19 is to follow health protocols. In North Aceh District, there are still many people who do not comply with the health protocol. This is because many people do not really believe in the Covid-19 disease. This study was aimed to identify the effect of the level of public trust about Covid-19 on compliance with health protocols during the Covid-19 pandemic. This type of research was quantitative analytical correlation design with cross sectional. Sampling technique used convenience sampling technique with a total of 175 respondents. Data analysis used Chi-Square test. The results showed that $67.4 \%$ of respondents had a level of trust in the distrust category and as many as $82.9 \%$ of respondents did not comply with health protocols. There is an influence on the level of public trust about Covid-19 on compliance with health protocols during the Covid-19 pandemic in Lueng Bata Village, Baktiya District, North Aceh Regency $(p=0.000)$. It is hoped that health workers, especially nurses, are more optimal in providing health education to increase public trust about Covid-19 so that people obey in carrying out health protocols.
\end{abstract}

Keywords: covid-19; obedience; health protocols; level of confidence 


\section{PENDAHULUAN}

Sejak tanggal 11 Maret 2020, ditetapkan pandemi akibat wabah Covid-19 diseluruh dunia. Covid-19 adalah penyakit yang disebabkan oleh virus corona (Widiyani, 2020). Virus corona terdeteksi muncul dan menyerang manusia pertama kali di provinsi Wuhan, China. Awal kemunculannya diduga merupakan penyakit pneumonia. Gejala yang timbul batuk, demam, letih, sesak napas dan tidak nafsu makan. Namun, berbeda dengan influenza, virus corona dapat berkembang dengan cepat hingga mengakibatkan infeksi lebih parah dan gagal organ serta kematian. Kondisi darurat ini terutama terjadi pada pasien dengan masalah kesehatan sebelumnya (Mona, 2020).

Saat ini virus corona masih terus menyebar ke seluruh dunia, data pertanggal 25 Oktober 2020 sebanyak 42,9 juta kasus terkonfirmasi di 216 negara dan lebih dari satu juta kasus $(2,7 \%)$ kematian (World Health Organization, 2020). Di Indonesia, pertanggal 25 Oktober 2020 sebanyak 396.454 kasus terkonfirmasi dan sebanyak $13.512 \quad(3,4 \%)$ orang meninggal (Kementerian Kesehatan Republik Indonesia, 2020).

Masyarakat harus menjalakan protokol kesehatan yang telah dianjurkan untuk mencegah penyebaran virus corona. Adapun protokol kesehatan yang telah ditetapkan yaitu menjaga jarak (physical distancing), mencuci tangan secara rutin dengan menggunkan sabun atau alkohol, menggunakan masker, jika batuk/bersin menutup mulut dengan tisu atau lengan dan membatasi aktivitas diluar rumah (Kementerian Kesehatan Republik Indonesia, 2020). Namun, pada kenyataannya masih banyak masyarakat tidak mematuhi semua protokol kesehatan tersebut.

Ketidakpatuhan ini dikarenakan banyak masyarakat yang tidak percaya dengan penyakit Covid-19. Kepercayaan adalah perilaku individu, yang mengharapkan seseorang agar memberi manfaat positif Deutsch (dalam Fahriah, 2015). Adanya kepercayaan karena individu yang dipercaya dapat memberi manfaat dan melakukan apa yang diinginkan oleh individu yang memberikan kepercayaan. Sehingga, kepercayaan menjadi dasar bagi kedua pihak untuk melakukan kerjasama (Deutsch dalam Fahriah, 2015).

Berdasarkan pernyataan Wakil Ketua Muhammadiyah Covid-19 Command Center Corona Ristawan masih banyaknya masyarakat yang tidak percaya dengan kebenaran adanya Covid-19 menyulitkan tenaga kesehatan untuk melakukan tracing. Ristawan (2020) juga mengatakan hal itu ditandai dengan adanya penolakan dari pasien probable Covid-19 atau PDP yang hendak dites setelah anggota keluarganya dikonfirmasi positif.

Berdasarkan studi pendahuluan yang dilakukan pada tanggal 10 Oktober 2020 di Desa Lueng Bata Kecamtan Baktiya Kabupaten Aceh Utara didapatkan bahwa dari 10 responden warga sebanyak 7 responden tidak mempercayai adanya virus corona dan sebanyak 3 responden belum begitu yakin dengan adanya virus corona. Dari hasil Berdasarkan hasil observasi peneliti didapatkan bahwa masih banyak warga yang berkerumun seperti duduk di kedai-kedai kopi dan tidak menggunakan masker. Tampak juga kedai-kedai kopi tidak menyediakan tempat cuci tangan ataupun hand sanitzer. Masih ada kegiatan-kegiatan yang mengumpulkan masa seperti acara resepsi pernikahan. Berdasarkan latar belakang diatas maka peneliti tertarik untuk melakukan penelitian tentang pengaruh tingkat kepercayaan masyarakat Covid-19 terhadap kepatuhan menjalankan protokol kesehatan.

\section{METODE}

Penelitian ini merupakan jenis penelitian quantitative design dengan pendekatan desain korelasi analitik dengan pendekatan desain berdasarkan waktu yaitu cross sectional. Populasi penelitian ini adalah seluruh masyarakat di Desa Lueng Bata Kecamatan Baktiya Kabupaten Aceh Utara yaitu sebanyak 311. Jumlah sampel yang akan diteliti yaitu sebesar 175 responden. Metode dalam pengambilan sampel yang digunakan adalah convenience sampling dimana metode penentuan sampel dengan memilih sampel secara bebas sekehendak peneliti (Sugiyono, 2015). 
Instrumen penelitian ini menggunakan kuesioner tingkat kepercayaan dan protokol kesehatan. Pada tahap pertama, peneliti menjelaskan maksud dan tujuan penelitian dengan mengajukan surat permohonan menjadi responden. masyarakat yang bersedia menjadi responden menandatangani surat pernyataan persetujuan untuk ikut serta dalam penelitian (informed consent). Tahap kedua, peneliti memberikan kuesioner kepada responden.

Sampel penelitian yang diambil adalah responden dengan kriteria inklusi yaitu bersedia menjadi responden, berusia 17 tahun keatas, dapat membaca dengan baik. Sedangkan kriteria eksklusi dalam penelitian ini adalah dengan alasan sepihak menghentikan keikutsertaan dalam penelitian. Analisis univariat dilakukan menggunakan analisis deskriptif melalui distribusi frekuensi dan persentase data yang meliputi umur, jenis kelamin, pendidikan dan pekerjaan. Analisis bivariat yang digunakan yaitu chi-square yang penggunaannya dibantu dengan aplikasi program komputer. Penelitian ini dinyatakan layak dilakukan berdasarkan surat yang di keluarkan oleh Lembaga Penelitian dan pengabdian Masayarakat (LPPM) Universitas Bina Bangsa Getsempena dengan Nomor: 044/131013.03/PPM/2021.

\section{HASIL}

\section{Karakterisitk Responden}

Berdasarkan tabel 1 dapat dilihat bahwa, sebanyak $62(35,4 \%)$ responden berada pada rentang usia 26-35 tahun (Dewasa Awal), sebanyak 123 (70,3\%) responden berjenis kelamin laki-laki, sebanyak 145 (82,9\%) responden berpendidikan menengah dan sebanyak 130 (74,3\%) responden memiliki pekerjaan sebagai petani.

Tabel 1 Distrubusi frekuensi dan persentase berdasarkan karakteristik responden di Desa Lueng Bata Kecamatan Baktiya Kabupaten Aceh Utara $(n=175)$

\begin{tabular}{llll}
\hline No & \multicolumn{1}{c}{$\begin{array}{c}\text { Karakteristik } \\
\text { Responden }\end{array}$} & $\boldsymbol{f}$ & $\%$ \\
\hline 1 & $\begin{array}{l}\text { Usia (Tahun) } \\
17-25 \text { (Remaja Akhir) }\end{array}$ & 12 & 6,9 \\
\hline
\end{tabular}

\begin{tabular}{clcc}
\hline \multicolumn{1}{c}{ 26-35 (Dewasa Awal) } & 62 & 35,4 \\
& 36-45 (Dewasa Tengah) & 60 & 34,3 \\
& 46-55 (Dewasa Akhir) & 32 & 18,3 \\
& 56-65 (Lansia Awal) & 9 & 5,1 \\
\hline 2 Jenis Kelamin & & \\
& Perempuan & 123 & 70,3 \\
& Laki-laki & 52 & 29,7 \\
\hline \multirow{2}{*}{3 Pendidikan } & & \\
& Dasar & 12 & 6,9 \\
& Menengah & 145 & 82,9 \\
& Tinggi & 18 & 39,4 \\
\hline 4 & Pekerjaan & & \\
& Swasta & 14 & 8 \\
& Pensiun & 4 & 2,3 \\
& Pedagang & 8 & 4,6 \\
& IRT & 6 & 3,4 \\
& Buruh & 6 & 3,4 \\
& Petani & 130 & 74,3 \\
& PNS & 7 & 4,0 \\
\hline
\end{tabular}

Tabel 2 disebutkan bahwa sebanyak $118(67,4 \%)$ responden memiliki tingkat kepercayaan dalam kategori tidak percaya.

Tabel 2 Distribusi Frekuensi dan Persentase Berdasarkan Tingkat Kepercayaan Masyarakat tentang Covid-19 di Desa Lueng Bata Kecamatan Baktiya Kabupaten Aceh Utara $(n=175)$

\begin{tabular}{clcc}
\hline No & \multicolumn{1}{c}{$\begin{array}{c}\text { Tingkat } \\
\text { Kepercayaan }\end{array}$} & $\boldsymbol{f}$ & $\%$ \\
\hline 1 & Percaya & 24 & 13,7 \\
2 & Kurang Percaya & 33 & 18,9 \\
3 & Tidak Percaya & 118 & 67,4 \\
\hline & Total & 175 & 100 \\
\hline
\end{tabular}

Tabel 3 menunjukkan bahwa sebanyak 145 $(82,9 \%)$ responden tidak patuh dalam menjalankan protokol kesehatan.

Tabel 3 Distribusi Frekuensi dan Persentase Berdasarkan Kepatuhan Menjalankan Protokol Kesehatan Masyarakat di Desa Lueng Bata Kecamatan Baktiya Kabupaten Aceh Utara $(n=175)$

\begin{tabular}{cccc}
\hline No & $\begin{array}{c}\text { Kepatuhan } \\
\text { Menjalankan Protokol } \\
\text { Kesehatan }\end{array}$ & $\boldsymbol{f}$ & $\%$ \\
\hline 1 & Patuh & 30 & 17,1 \\
2 & Tidak Patuh & 145 & 82,9 \\
\hline \multicolumn{2}{r}{ Total } & 175 & 100 \\
\hline
\end{tabular}




\section{Pengaruh Tingkat Kepercayaan Masyarakat Tentang Covid-19 Terhadap Kepatuhan Menjalankan Protokol Kesehatan Pada Masa Pandemi Covid-19}

Tabel 4 didapatkan bahwa sebanyak $24(13,7 \%)$ responden yang memiliki tingkat kepercayaan dengan kategori percaya dimana sebanyak $20(11,4 \%)$ responden patuh dalam menjalankan protokol kesehatan pada masa pandemi Covid-19 dan sebanyak 4 (2,3\%) responden tidak patuh dalam menjalankan protokol kesehatan pada masa pandemi Covid19. Kemudian, sebanyak 33 (18,9\%) responden memiliki tingkat kepercayaan dengan kategori kurang percaya dimana sebanyak 4 (2,3\%) responden patuh dalam menjalankan protokol kesehatan pada masa pandemi Covid-19 dan sebanyak 29 (16,6\%) responden tidak patuh dalam menjalankan protokol kesehatan pada masa pandemi Covid19. Sedangkan, dari $118(67,4 \%)$ responden memiliki tingkat kepercayaan dengan kategori tidak percaya dimana sebanyak $6 \quad(3,4 \%)$ responden patuh dalam menjalankan protokol kesehatan pada masa pandemi Covid-19 dan sebanyak 112 (64\%) responden tidak patuh dalam menjalankan protokol kesehatan pada masa pandemi Covid-19.

Selanjutnya uji statistik menunjukkan dengan menggunakan uji Chi Square mendaatkan hasil nilai $p=0,000<0,05$, maka $\mathrm{HO}$ ditolak yang artinya ada pengaruh tingkat kepercayaan masyarakat tentang Covid-19 terhadap kepatuhan menjalankan protokol kesehatan pada masa pandemi Covid-19 masyarakat di desa Lueng Bata Kecamatan Baktiya Kabupaten Aceh Utara

Tabel 4 Pengaruh Tingkat Kepercayaan Masyarakat Tentang Covid-19 Terhadap Kepatuhan Menjalankan Protokol Kesehatan Pada Masa Pandemi Covid-19 Masyarakat di Desa Lueng Bata Kecamatan Baktiya Kabupaten Aceh Utara $(n=175)$

\begin{tabular}{|c|c|c|c|c|c|c|c|c|}
\hline \multirow{3}{*}{ No } & \multirow{3}{*}{ Tingkat Kepercayaan } & \multicolumn{4}{|c|}{$\begin{array}{l}\text { Kepatuhan Menjalankan Protokol } \\
\text { Kesehatan }\end{array}$} & \multirow{3}{*}{ Total } & \multirow{3}{*}{$\%$} & \multirow{3}{*}{$p$-value } \\
\hline & & \multicolumn{2}{|c|}{ Patuh } & \multicolumn{2}{|c|}{ Tidak Patuh } & & & \\
\hline & & $f$ & $\%$ & $F$ & $\%$ & & & \\
\hline 1 & Percaya & 20 & 11,4 & 4 & 2,3 & 4 & 13,7 & \\
\hline 2 & Kurang Percaya & 4 & 2,3 & 29 & 16,6 & 33 & 18,9 & 0,000 \\
\hline \multirow[t]{2}{*}{3} & Tidak Percaya & 6 & 3,4 & 112 & 64 & 118 & 67,4 & \\
\hline & Total & 30 & 17,1 & 145 & 82,9 & 175 & 100 & \\
\hline
\end{tabular}

\section{PEMBAHASAN}

\section{Gambaran Tingkat Kepercayaan tentang Covid-19 di Desa Lueng Bata}

Berdasarkan hasil penelitian dari 175 responden didapatkan bahwa sebanyak 67,4\% responden memiliki tingkat kepercayaan dalam kategori tidak percaya. Hasil penelitian ini didukung oleh Mufti et al., (2020) menunjukkan bahwa pada pada masyarakat sipil memiliki rata-rata skor tingkat kepercayaan dalam kriteria tidak percaya. Hasil penelitian ini juga sejalan dengan penelitian Winarso et al., (2020) menunjukkan bahwa dari 30 responden di Kober Mie Setan Kabupaten Jember sebanyak 95\% responden menyatakan jika mengalami penularan Covid-19 merupakan takdir dan tidak harus diawali dengan usaha pencegahan. Responden juga menyatakan jika terinfeksi Covid-19 maka dapat sembuh dengan sendirinya, tingkat kepercayaan yang kurang juga disebabkan keterbaruan informasi tentang Covid-19 masih kurang. Menurut Ristawan (2020) masih banyak masyarakat yang tidak percaya dengan kebenaran adanya Covid-19 menyulitkan tenaga kesehatan untuk melakukan tracing. Hasil survey Charta Politika (2021) menunjukkan bahwa masih banyak masyarakat tidak mempercayai informasi tentang Covid-19 yaitu sebesar 43,3\%.

Hasil Survey di Jakarta dan Surabaya yang dilakukan oleh Nanyang Technological University (NTU) mendapatkan hasil banyak masyarakat yang masih yakin tidak akan tertular Covid-19 (Amir, 2020b). Hasil penelitian Wong dan Jensen (2020) di Singapura menyatakan sebagian besar masyarakat 
meyakini tidak akan tertular covid-19. Kepercayaan kesehatan adalah perilaku kesehatan ditentukan oleh kepercayaan individu atau persepsi tentang penyakit dan cara yang tersedia untuk mengurangi kejadiannya (Rosenstock, 1974).

Tingkat kepercayaan masyarakat dapat dikaitkan dengan usia responden. Hasil penelitian didapatkan bahwa sebanyak 35,4\% responden berusia antara 26-35 tahun. Menurut Arya (2020) sebanyak 63,6\% anak muda di Jakarta berusia 24-39 tahun tidak percaya terhadap Covid-19. Hasil survey yang dilakukan Indikator Politik Indonesia juga menunjukkan hanya 45,1 \% kelompok usia 2225 tahun yang percaya terhadap Covid-19. Hasil survei Amir seorang Profesor Sosiologi Bencana NTU menunjukkan sebanyak 64\% warga Bogor merasa aman dari ancaman Covid-19 dengan rentang usia 36-46 tahun diikuti oleh usia 26-35 tahun (Amir, 2020a). Menurut Kamil (dalam Anugerah, 2021) kelompok usia muda mungkin lebih jarang mengeluh mengalami gangguan kesehatan sehingga masih usai muda lebih menganggap remeh terhadap Covid-19.

Berdasarkan pendidikan, dapat dilihat bahwa sebanyak $82,9 \%$ responden berpendidikan menengah. Hasil penelitian (Romziyah, 2020) juga menunjukkan sebgaian besar responden (39\%) berpendidikan SMA. Menurut Notoatmodjo (2012), tingkat pendidikan dapat mempengaruhi tingkat pengetahuan responden tentang kesehatan oleh karena kemampuan seseorang dalam menerima dan memahami ditentukan oleh tingkat pendidikan yang dimiliki. Penerimaan dan pemahaman terhadap informasi kesehatan yang diterima seseorang yang berpendidikan tinggi lebih baik dibandingkan dengan seseorang yang berpendidikan rendah.

Berdasarkan pekerjaan, dapat dilihat bahwa sebanyak $74,3 \%$ responden memiliki pekerjaan sebagai petani. Jika pekerjaan bergerak dalam bidang kesehatan, maka informasi yang didapat mengenai Covid-19 dapat meningkat, dan informasi tersebut dapat disebarkan ke masyarakat dan berpengaruh terhadap tingkat kepercayaan masyarakat tentang Covid-19 (Mashabi, 2020). Tingkat kepercayaan masyarakat tentang Covid-19 dapat dikaitkan dengan usia, pendidikan dan pekerjaan dari masyarakat itu sendiri. Tingkat kepercayaan juga dapat dikaitkan dengan penerimaan informasi masyarakat.

\section{Gambaran Kepatuhan Menjalankan Protokol Kesehatan Pada Masa Pandemi di Desa Lueng Bata}

Berdasarkan hasil penelitian dari 175 responden didapat bahwa sebanyak 82,9\% responden tidak patuh dalam menjalankan protokol kesehatan. Hasil penelitian ini didukung oleh Wong \& Jensen (2020) menyatakan bahwa kepatuhan masyarakat rendah terhadap protokol kesehatan pencegahan Covid-19. Menurut Ketua Satgas Covid-19 Warsito (2021) mengatakan bahwa ada penurunan kepatuhan menjalankan protokol kesehatan pada masayarakat. Hasil penelitian Simanjuntak et al., (2020) juga menunjukkan bahwa kepatuhan protokol kesehatan sebanyak 47,16\% responden.

Hasil penelitian yang dilakukan oleh Rizka et al., (2021) juga menunjukkan sebanyak $78,3 \%$ responden memiliki sikap negatif dalam menjalankan protokol kesehatan. Juru bicara Presiden dr. Yurianto (dalam (Kementerian Kesehatan Republik Indonesia, 2020) menyatakan kepatuhan masyarakat dalam menjalankan protokol kesehatan belum optimal. Hasil penelitian (Budilaksana, 2021) juga menunjukkan sebanyak $71,3 \%$ responden tidak patuh dalam melaksanakan protokol kesehatan.

Kepatuhan merupakan perilaku positif yang diperlihatkan masyarakat saat masyarakat menjalankan protokol kesehatan (Sari \& Atiqoh, 2020). Menurut Kozier dan Erb, (2010) kepatuhan adalah perilaku sesuai anjuran terapi dan kesehatan dan dapat dimulai dari tindak mengindahkan setiap aspek anjuran hingga mematuhi rencana. Sedangkan Albery dan Munafo (2011) menyatakan bahwa kepatuhan mengacu kepada situasi ketika perilaku seorang individu sepadan dengan tindakan yang dianjurkan atau nasehat yang diusulkan oleh seorang praktisi kesehatan atau 
informasi yang diperoleh dari suatu sumber informasi lainnya.

Berdasarkan usia, sebanyak 35,4\% responden berusia antara 26-35 tahun. Hasil penelitian Afrianti dan Rahmiati (2021) menunjukkan sebagian besar responden pada kategori dewasa $(72,4 \%)$ (Afrianti \& Rahmiati, 2021). Pura (dalam Afrianti \& Rahmiati, 2021) menyatakan bahwa usia berhubungan dengan tingkat kepatuhan, semakin tua usia pasien maka akan semakin menurun daya ingat, pendengaran, dan penglihatan, sehingga pasien lansia menjadi tidak patuh.

Berdasarkan jenis kelamin, dalam penelitian ini sebanyak $70,3 \%$ responden berjenis kelamin laki-laki. Penelitian ini sejala dengan penelitian Budilaksana (2021)dimana sebagian besar responden berjenis kelamian laki-laki. Penelitian oleh Wiranti. et al., (2020) mengungkakan bahwa responden dengan kepatuhan tinggi banyak dilakukan oleh responden perempuan. Hal ini dapat didasari adanya perbedaan sifat pada setiap gender. Menurut Aubee dalam penelitian Kurniasari (2013), perempuan memiliki sifat penuh kasih sayang, merasa bertanggung jawab terhadap kesejahteraan orang di sekitarnya, serta lembut. Sementara laki-laki cenderung memiliki sifat agresif, senang berpetualang, kasar, suka keleluasaan dan lebih berani mengambil risiko. Dalam konteks ini risiko yang ada salah satunya yaitu risiko tertular Covid-19. Sehingga adanya perbedaan sifat ini dapat menyebabkan perempuan cenderung lebih takut untuk melanggar peraturan.

Berdasarkan pendidikan, dapat dilihat bahwa sebanyak 82,9\% responden berpendidikan menengah. Hasil penelitian ini didukung oleh Sudiro dan Watimena (2020) menunjukkan pendidikan responden sebagian besar yaitu menengah (54,5\%). Hasil penelitian Romziyah juga menunjukkan sebagian besar pendidikan responden yaitu menengah (39\%).

$$
\text { Pendidikan menjadi media }
$$

pembelajaran pada bagi masyarakat luas dengan tujuan agar dapat melaksanakan tindakan (praktik) tepat dan baik sehingga dapat memelihara (mengatasi) permasalahan guna melanjutkan keberlangsungan hidupnya secara sehat. Secara langsung dan atau tidak langsung tingkat seseorang atau masyarakat sadar akan pentingnya perilaku hidup sehat dipengaruhi tingkat pendidikannya yang akhirnya pendidikan tersebut akan dapat mempengaruhi kemampuan dalam upaya atau usaha melaksanakan hidup sehat (Kurniasari, 2013).

\section{Pengaruh Tingkat Kepercayaan Masyarakat Tentang Covid-19 Terhadap Kepatuhan Menjalankan Protokol Kesehatan Pada Masa Pandemi Covid-19 Masyarakat di Desa Lueng Bata}

Berdasarkan hasil penelitian yang menunjukkan ada pengaruh tingkat kepercayaan masyarakat tentang Covid-19 terhadap kepatuhan menjalankan protokol kesehatan pada masa pandemi Covid-19 masyarakat di desa Lueng Bata Kecamatan Baktiya Kabupaten Aceh Utara $(p=0,000)$. Hasil penelitian ini sejalan dengan penelitian yang dilakukan oleh Budilaksana (2021) yang mendapatkan hasil ada hubungan antara nilai dan keyakinan dengan kepatuhan pelaksanaan protokol kesehatan pada Masyarakat Desa Kasiyan Kabupaten Jember.

Hasil penelitian Afrianti dan Rahmiati (2021) juga menunjukkan ada hubungan antara tingkat kepercayaan dengan kepatuhan dalam menjalankan protokol kesehatan pada masa pandemi Covid-19. Penelitian Webster et al., (2020) juga menyatakan bahwa adanya hubungan kepercayaan tentang Covid-19 dengan mematuhi peraturan penanganan dan pencegahan Covid-19. Hasil penelitian Diana et al (2021) juga menunjukkan bahwa ada hubungan antara tingkat kepercayaan dengan kepatuhan protokol kesehatan pada masyarakat Surabaya. Hasil penelitian (Fahik, 2021) juga menunjukkan ada hubungan tingkat kepercayaan terhadap protokol kesehatan Covid-19.

Ketua Prodi Pendidikan Sosiologi dan Antropologi FKIP UNS (Nurhadi, 2020) kepada Kompas.com tahun 2020 mengatakan "banyak masyarkat yang tidak patuh menjalankan protokol kesehatan karena masih adanya orang-orang yang tidak percaya akan adanya virus Covid-19". Lebih lanjut, Nurhadi mengatakan masyarkat lebih khawatir 
kehilangan pekerjaan atau tidak bisa makan daripada takut dengan Covid-19.

Kepercayaan atau trust merupakan wilayah psikologis yang merupakan perhatian untuk menerima apa adanya berdasarkan harapan terhadap perilaku yang baik dari orang lain (Rosseau dalam Juni, 2017). Kepercayaan oleh didefenisikan sebagai keyakinan satu pihak pada reliabilitas, durabilitas, dan integritas pihak lain dalam relationship dan keyakinan bahwa tindakannya merupakan tindakan yang paling baik dan akan menghasilkan hasil positif bagi pihak yang dipercaya (Maharani, 2010). Tingkat kepercayaan masayarakat tentang Covid-19 turut berperan dalam menjalankan kepatuhan dalam penerapan protokol kesehatan Covid19.

Berdasarkan informasi yang didapat peneliti di Desa Lueng Bata, ketidakpatuhan menjalankan protokol kesehatan disebabkan karena banyak masyarakat tidak percaya dengan adanya Covid-19 dan mereka tidak akan terinfeksi Covid-19. Masyarakat percaya penyakit itu datangnya dari Tuhan Yang Maha Esa. Jika harus terkena penyakit sudah takdir dari Allah sehingga banyak masyarakat yang tidak patuh dalam menjalankan protokol kesehatan.

Menurut asumsi peneliti ketidakpatuhan menjalankan protocol kesehatan disebabkan karena masyarakat tidak percaya dengan adanya Covid-19 dan dapat juga dikaitkan dengan karakterisitik dari masyarakat di Desa Lueng Bata Kecamatan Baktiya Kabupaten Aceh Utara.

Hasil penelitian di Desa Lueng Bata Kecamatan Baktiya Kabupaten Aceh Utara tentang Pengaruh Tingkat Kepercayaan Masyarakat Tentang Covid-19 Terhadap Kepatuhan Menjalankan Protokol Kesehatan Pada Masa Pandemi Covid-19 Di Desa Lueng Bata Kecamatan Baktiya Kabupaten Aceh Utara didapatkan ada pengaruh tingkat kepercayaan masyarakat tentang Covid-19 terhadap kepatuhan menjalankan protokol kesehatan pada masa pandemi Covid-19.

\section{KESIMPULAN}

Berdasarkan hasil penelitian dapat disimpulkan bahwa sebanyak $35,4 \%$ responden berada pada rentang usia 26-35 tahun (Dewasa Awal), sebanyak 70,3\% responden berjenis kelamin laki-laki, sebanyak $82,9 \%$ responden berpendidikan menengah dan sebanyak $74,3 \%$ responden memiliki pekerjaan sebagai petani. Sebanyak $67,4 \%$ responden memiliki tingkat kepercayaan dalam kategori tidak percaya. Sebanyak $82,9 \%$ responden tidak patuh dalam menjalankan protokol kesehatan. Berdsasarkan uji statistik menunjukkan ada pengaruh tingkat kepercayaan masyarakat tentang Covid-19 terhadap kepatuhan menjalankan protokol kesehatan pada masa pandemi Covid-19 masyarakat di desa Lueng Bata Kecamatan Baktiya Kabupaten Aceh Utara $(p=0,000)$. Diharapkan petugas kesehatan terutama perawat lebih optimal dalam memberikan pendidikan kesehatan untuk meningkatkan kepercayaan masyarakat tentang Covid-19 sehingga masyarakat patuh dalam menjalankan protokol kesehatan.

\section{REFERENSI}

Afrianti, N., \& Rahmiati, C. (2021). Faktor-Faktor Yang Mempengaruhi Kepatuhan Masyarakat Terhadap Protokol Kesehatan Covid-19. Jurnal IImiah Permas: Jurnal IImiah STIKES Kendal, 11(1), 113-124.

Albery, P. I., \& Munafo, M. (2011). Psikologi Kesehatan Panduan Lengkap dan Komprehensif Bagi Studi Psikologi Kesehatan (Cetakan I). Palmall.

Amir, S. (2020a). Banyak Orang Indonesia Nilai Positif Covid, Pakar Sosiologi Bencana: Mereka Ingin Pandemi Terus Berlanjut. Pikiran Rakyat. https://galamedia.pikiran-rakyat.com/news/pr352712194/banyak-orang-indonesia-nilaipositif-covid-pakar-sosiologi-bencana-merekaingin-pandemi-terus-berlanjut

Amir, S. (2020b). Survei: Mayoritas Warga Surabaya Cenderung Anggap Enteng Risiko Terkena Covid-19. Kompas.Com. https://regional.kompas.com/read/2020/07/16/1 6443351/survei-mayoritas-warga-surabayacenderung-anggap-entengrisiko-terkenacovid?page=all.

Anugerah, P. (2021). Covid-19: Dua survei menyebut banyak anak muda menolak vaksin, bagaimana meyakinkan mereka? BBC. https://www.bbc.com/indonesia/indonesia56150289.

Arya, F. (2020). Persepsi, Efektivitas dan Kepatuhan 
Masyarakat dalam Peneraparan Protokol Kesehatan Covid-19. https://www.csis.or.id/publications/persepsiefektivitas-dan-kepatuhan-masyarakat-dalampeneraparan-protokol-kesehatan-covid-19

Budilaksana, S. (2021). Faktor-Faktor Kepatuhan Pelaksanaan Protokol Kesehatan dalam Menghadapi Pandemi Covid-19 Pada Masyarakat di Desa Kasiyan Kabupaten Jember. Universitas Muhammdiyah Jember.

Charta Politika. (2021). Tingkat Kepercayaan terhadap Data Covid-19 Milik Pemerintah. Charata Politika.

https://databoks.katadata.co.id/datapublish/202 1/08/12/charta-politika-433-warga-tidakpercaya-data-Covid-19-pemerintah.

Diana, Z., Suroso, \& Noviekayati., I. (2021). Hubungan antara Persepsi Risiko COVID-19 dan SelfEfficacy Menghadapi Covid-19 dengan Kepatuhan terhadap Protokol Kesehatan pada Masyarakat Surabaya. Mind Set, 1(1), 105116.

Fahik, P. F. (2021). Analisis Faktor Risiko Tingkat Kepatuhan Pelaku Perjalanan Terhadap Protokol Kesehatan Covid-19 Selama Dan Setelah Periode Isolasi Mandiri 14 Haridi Kabupaten Malaka. Universitas Nusa Cendana.

Fahriah, R. (2015). Perbedaan Kepercayaan Interpersonal Pada Mahasiswa dan Karyawan Bagian Administrasi Pada Universitas Borneo di Tarakan. Psychology Forum UMM, 306-310.

Juni, P. . (2017). Perilaku Konsumen: Dalam Persaingan Bisnis Kontemporer. Alfabeta.

Kementerian Kesehatan Republik Indonesia. (2020). Pedoman Pencegahan dan Pengendalian Coronavirus Disesase (COVID-19) Revisi Ke-5. In Kementerian Kesehatan Republik Indonesia. Sub Direktorat Penyakit Infeksi Emerging, Direktorat Surveilans dan Karantina Kesehatan, Direktorat Jenderal Pencegahan dan Pengendalian Penyakit.

Kozier, B., \& Erb, G. (2010). Buku Ajar Fundamental Keperawatan. EGC.

Kurniasari, N. D. (2013). Perbedaan Sikap Disiplin Berlalu Lintas Ditinjau Dari Jenis Kelamin. Universitas Muhamdiyah Surakart.

Maharani, A. D. (2010). Analisis Pengaruh Kepercayaan dan Kepuasan Terhadap Loyalitas Nasabah Tabungan Bank Mega Syariah Cabang Semarang. Universitas Diponegoro Semarang.

Mashabi, S. (2020). Mobilitas Penduduk DKI yang Tinggi Sebabkan Peningkatan Kasus Covid-19. Kompas.Com. https://nasional.kompas.com/read/2020/03/17/ 17244001/mobilitas-pendudukdki-yang-tinggisebabkan-peningkatan-kasus-COVID-19

Mona, N. (2020). Konsep Isolasi Dalam Jaringan Sosial Untuk Meminimalisasi Efek Contagious (Kasus Penyebaran Virus Corona Di Indonesia). Jurnal
Sosial Humaniora Terapan, 2(2), 117-125. https://doi.org/10.7454/jsht.v2i2.86

Mufti, M., Gatara, A. A. S., Afrilia, A., \& Mutiarawati, R. (2020). Analisis pengukuran tingkat kepercayaan publik terhadap pemerintah: Kekuatan bagi penanganan Covid-19 berbasis masyarakat. Naskah Publikasi, 1-13. http://digilib.uinsgd.ac.id/id/eprint/31704

Notoatmodjo, S. (2012). Promosi Kesehatan dan Perilaku Kesehatan. Rineka Cipta.

Nurhadi. (2020). Kasus Covid-19 Terus Menanjak, Apa Penyebab Masyarakat Semakin Abai Protokol Kesehatan? Kompas.Com. https://www.kompas.com/tren/read/2020/12/04/ 204700765/kasus-Covid-19-terus-menanjakapa-penyebab-masyarakat-semakin-abaiprotokol?page $=$ all

Ristawan. (2020). Rendahnya Kepercayaan Masyarakat Terhadap Covid-19 Mempersulit Tracing. Kabar24.

https://kabar24.bisnis.com/read/20200806/15/1 275942/rendahnya-kepercayaan-masyarakatterhadap-Covid-19-mempersulit-tracing

Rizka, S. F., Amelia, A. R., \& Haeruddin. (2021). Hubungan Perilaku Masyarakat Dengan Kepatuhan Penggunaan Masker Untuk Memutus Rantai Penularan Covid-19 Di Kelurahan Bontoa Maros. Journal of Muslim Community Health (JMCH), 2(3), 165-175.

Romziyah, B. (2020). Hubungan Tingkat Pengetahuan Dan Sikap Masyarakat Dalam Upaya Pencegahan Covid-19 Menggunakan Immunomodulator Herbal di Desa Kenteng Kecamatan Susukan Kabupaten Semarang. Universitas Ngadi Waluyo.

Rosenstock, I. M. (1974). Historical Origins of the Health Belief Model. Health Education Monographs, 2(4), 328-335.

S, W., Irfiah, Y, S., A, S., K, A., \& Z, W. A. (2020). Gambaran Health Literacy, Pengetahuan , Kepercayaan , Sikap ,. Multidisciplinary Journal, 3(1), 41-49.

Sari, N., \& Atiqoh. (2020). Hubungan Antara Pengetahuan Masyarakat Dengan Kepatuhan Penggunaan Masker Sebagai Upaya Pencegahan Penyakit Covid-19 Di Ngronggah. Jurnal IImiah Rekam Medis Dan Informatika Kesehatan, 10(1), 52-55.

Simanjuntak, D. R., Napitupulu, T. M., Wele, A. M., \& Yanie, R. (2020). Gambaran Kepatuhan Masyarakat Menerapkan Protokol Kesehatan Covid-19 di Tempat Umum Periode September 2020 di DKI Jakarta. Universitas Kristen Indonesia.

Sudiro, A., \& Watimena, L. (2020). Sikap dan Prilaku Masyarakat Indonesia Terhadap Pandemi Virus Corona (Covid-19) di Indonesia. Jurnal Kedokteran Dan Kesehatan: Publikasi IImiah Fakultas Kedokteran Universitas Sriwijaya, 7(5), 150-155. 
https://doi.org/10.32539/JKK.V7I3.11275

Sugiyono. (2015). Metode Penelitian Kombinasi (Mix Methods) (Issue September). Alfabeta.

Warsito, G. (2021). Ketua Satgas Covid-19: Kepatuhan Prokes Masyarakat Turun. Tribunnews.Com. https://www.tribunnews.com/corona/2021/07/0 7/ketua-satgas-Covid-19-kepatuhan-prokesmasyarakat-turun

Webster, R. K., Brooks, S. K., Smith, L. E., Woodland, L., Wessely, S., \& Rubin, G. J. (2020). How to Improve Adherence with Quarantine: Rapid Review of The Evidence. Public Health, 182, 163-169.

https://doi.org/https://doi.org/10.1016/j.puhe.20 20.03.007

Widiyani, R. (2020). Latar Belakang Virus Corona, Perkembangan hingga Isu Terkini. Detik News. https://news.detik.com/berita/d4943950/latarbelakangviruscoronaperkembangan-hinggaisuterkini Nuha Medika
Wiranti., Sriatmi, A., \& Kusumastuti, W. (2020). Determinan Kepatuhan Masyarakat Kota Depok Terhadap Kebijakan Pembatasan Sosial Berskala Besar Dalam Pencegahan Covid-19. Jurnal Kebijakan Kesehatan Indonesia, 9(3), 121-124. https://doi.org/https://doi.org/10.22146/jkki.584 84

Wong, C. M. L., \& Jensen, O. (2020). The paradox of trust: perceived risk and public compliance during the COVID-19 pandemic in Singapore. Journal of Risk Research, 23(7-8), 1021-1030. https://doi.org/10.1080/13669877.2020.175638 6

World Health Organization. (2020). Coronavirus disease (COVID-19) Weekly Epidemiological Update and Weekly Operational Update. https://www.who.int/emergencies/diseases/nov el-coronavirus-2019/situation-reports. 